\title{
Pengaruh Perbedaan Tinggi Tumpukan Kompos terhadap Jumlah Bakteri Escherichia coli dan Salmonella sp. pada Kompos Sampah Organik Pasar dan Limbah Padat Rumah Potong Hewan
}

Nada Pirma Sari, Rinaldi, dan Zuli Rodhiyah

Teknik Lingkungan, Fakultas Sains dan Teknologi, Universitas Jambi, Jambi, Indonesia

Email: nadapirmasari@gmail.com, rinaldi@unja.ac.id, zuli.rodhiyah@unja.ac.id

\section{Info Artikel}

Diterima:

Disetujui:

Dipublikasikan:

\section{Alamat Korespondensi: nadapirmasari@gmail.com \\ Copyright (C) 2020 Jurnal Engineering}

This work is licensed under the Creative Commons Attribution International License (CC BY 4.0).

\begin{abstract}
Abstrak
Pasar Angso Duo Kota Jambi setiap harinya menghasilkan 54 $\mathrm{m}^{3}$ sampah dan sebanyak $1.288 \mathrm{~kg} /$ tahun limbah padat dihasilkan dari Rumah Potong Hewan (RPH) Kota Jambi. Sebagai upaya mengurangi jumlah timbulan sampah dan limbah padat $\mathrm{RPH}$, maka dilakukan penelitian dengan memanfaatkan sampah organik pasar dan limbah padat RPH sebagai bahan baku kompos. Pengomposan dilakukan dengan metode aerobik-open windrow dan membandingkan 2 variasi tinggi tumpukan kompos untuk dilihat pengaruhnya terhadap jumlah bakteri Escherichia coli dan Salmonella sp. Hasil penelitian menunjukkan bahwa perbedaan tinggi tumpukan kompos mempengaruhi pencapaian suhu kompos. Kompos mencapai suhu tertinggi $63^{\circ} \mathrm{C}$ pada tinggi tumpukan $0,6 \mathrm{~m}$ (T-I) dan $64^{\circ} \mathrm{C}$ pada tinggi tumpukan $1 \mathrm{~m}$ (T-II). Jumlah bakteri Escherichia coli mengalami penurunan jumlah pada komposter T-I dan T-II menjadi $220 \mathrm{MPN} / \mathrm{gr}$ dan $130 \mathrm{MPN} / g r$ pada hari ke-45 pengomposan. Namun, jumlah ini belum sesuai dengan yang disyaratkan pada Peraturan Menteri Pertanian No. 70 tahun 2011 tentang Pupuk Organik, Pupuk Hayati dan Pembenah Tanah. Sedangkan, kompos pada penelitian ini bebas dari kontaminasi bakteri Salmonella sp. Perbedaan tinggi tumpukan kompos tidak menghasilkan perbedaan yang mencolok untuk parameter kematangan kompos yaitu warna, bau dan tekstur kompos. Parameter kematangan kompos sudah sesuai dengan SNI 14-7030-2004 tentang Spesifikasi Kompos dari Sampah Organik Domestik.
\end{abstract}

Kata kunci: Escherichia coli; Pengomposan; Salmonella sp.

\section{Abstract:}

Angso Duo Market in Jambi City produced $54 \mathrm{~m}^{3}$ of waste everyday, and as much as $1.288 \mathrm{~kg} /$ year solid waste are produced in slaughterhouse in Jambi City. As an effort to reduce that waste and solid waste from slaughterhouse, this research is used waste and solid waste from slaughterhouse as raw material for composting. This research used an aerobic-open windrow method for composting, and compare the compost pile with 2 variances of height to find out it's effect on the 
amount of bacteria Escherichia coli and Salmonella sp. This research showed that the compost pile with difference height has affected the temperature attainment. The maximum temperature of compost pile with $0,6 \mathrm{~m}$ height $(\mathrm{T}-\mathrm{I})$ is $63^{\circ} \mathrm{C}$ and $64^{\circ} \mathrm{C}$ at compost pile with $1 \mathrm{~m}$ height (T-II). The amount of bacteria Escherichia coli has decreased at composter T-I and T-II, the amount of bacteria was $220 \mathrm{MPN} / \mathrm{gr}$ and $130 \mathrm{MPN} / g r$ on day 45 of composting. However, this amount does not meet the requirements of the regulation No 70 in 2011 about Organic Fertilizers, Biological Fertilizers and Soil Repairers from Ministry of Agriculture. Meanwhile, the compost in this research was free from Salmonella sp. The difference in the height of compost pile did not make any significant differences for compost maturity parameters, such as colors, smells and texture from the compost. Compost maturity parameters are appropriate with SNI 14-7030-2004 regarding Compost Specifications from Domestic Organic Waste.

Keywords: Composting; Escherichia coli; Salmonella sp.

\section{Pendahuluan}

Pasar Angso Duo Kota Jambi menghasilkan sampah sebanyak $54 \mathrm{~m}^{3} /$ hari dan $75 \%$ diantaranya merupakan sampah organik (Marolop, 2015). Sampah tersebut dikumpulkan dan kemudian diangkut menuju Tempat Pemrosesan Akhir (TPA) Talang Gulo Kota Jambi tanpa dilakukan pengolahan terlebih dahulu. Hal ini dikhawatirkan akan semakin memperluas penggunaan lahan di TPA. Selain itu, Rumah Potong Hewan (RPH) Kota Jambi menghasilkan limbah padat sebanyak $1.288 \mathrm{~kg} / \mathrm{tahun}$. Limbah ini dikumpulkan pada suatu bak penampung tanpa dilakukan pengolahan, sehingga dikhawatirkan dapat menjadi penyebaran bibit penyakit. Sebagai upaya mengurangi jumlah timbulan sampah dari Pasar Angso Duo Kota Jambi, maka dilakukan penelitian dengan memanfaatkan sampah organik pasar dengan campuran limbah padat RPH sebagai bahan baku kompos.

Limbah padat RPH berupa kotoran sapi pada proses pengomposan dapat memacu dekomposisi kompos karena bertambahnya mikroorganisme (Erwiyono, 1994). Pengolahan kotoran sapi dengan kandungan nitrogen $(\mathrm{N})$, posfor $(\mathrm{P})$, dan kalium $(\mathrm{K})$ yang tinggi menjadi kompos dapat mensuplai unsur hara dan memperbaiki struktur tanah (Setiawan, 2002). Selain itu, isi rumen sapi juga dapat bertindak sebagai bioaktivator yang di dalamnya mengandung mikroorganisme efektif yang secara aktif dapat mempercepat proses dekomposisi sampah organik (Tarigan, 2012). Namun, perlu diperhatikan dari parameter mikrobiologis kompos karena didalam limbah padat RPH masih terdapat bakteri patogen berupa bakteri Escherichia coli dan Salmonella sp. yang dapat menyebabkan penyebaran bibit penyakit.

Proses pengomposan juga dapat berlangsung dengan cepat apabila dalam kondisi aerobik atau cukup oksigen (Murbandono, 2008). Sistem aerasi pada proses pengomposan dapat dilakukan dengan mekanisme pengadukan, meskipun pengadukan akan mempengaruhi pencapaian suhu selama proses pengomposan. Namun, apabila selama proses pengomposan suhu kompos mampu mencapai suhu di atas $55^{\circ} \mathrm{C}$ maka dapat menghilangkan bakteri-bakteri patogen yang ada di dalam kompos (Amanah, 2012). Oleh karena itu, dalam penelitian ini pengomposan dilakukan dengan membandingkan tinggi tumpukan kompos untuk dilihat pengaruhnya terhadap jumlah bakteri Escherichia coli dan Salmonella sp. sehingga dihasilkan kompos yang sesuai dengan Peraturan Menteri Pertanian Nomor 70 Tahun 2011 tentang Pupuk Organik, Pupuk Hayati dan Pembenah Tanah.

\section{Metode Penelitian}

a. Waktu dan Tempat Penelitian

Penelitian ini dilakukan selama kurang lebih 3 bulan, pada bulan November dan Desember tahun 2019 serta bulan Januari tahun 2020. Penelitian ini dilaksanakan di Rumah Kompos TPA Talang Gulo 
Kota Jambi. Pengujian terhadap parameter mikrobiologis kompos dilakukan di Laboratorium Balai Kesehatan Daerah Provinsi Jambi. Pengambilan sampah organik pasar dari Tempat Penampungan Sementara (TPS) Pasar Angso Duo Kota Jambi. Serta, limbah padat diambil dari RPH Kota Jambi.

\section{b. Prosedur Penelitian}

Persiapan penelitian

Sebelum melakukan penelitian, dilakukan persiapan-persiapan yang mendukung dalam pelaksanaan penelitian. Adapun persiapan penelitian dimulai dari menyiapkan komposter. Penelitian ini menggunakan metode aerobik-open windrow untuk melakukan pengomposan. Komposter yang digunakan merupakan komposter sederhana yang disesuaikan dengan cara kerja metode pengomposan open windrow (Gambar 1). Ukuran komposter disesuaikan dengan kebutuhan dan mengikuti bentuk dari rancangan komposter penelitian Hutagalung (2012). Komposter dibuat dari kerangka besi dan dinding fiber berbentuk bak dengan volume $0,36 \mathrm{~m}^{3}$. Komposter diberi lubang sebesar \pm 1 inch dengan jarak yang tidak ditentukan tetapi dengan pertimbangan lubang yang dibuat akan cukup untuk menyuplai udara yang masuk kedalam kompos.

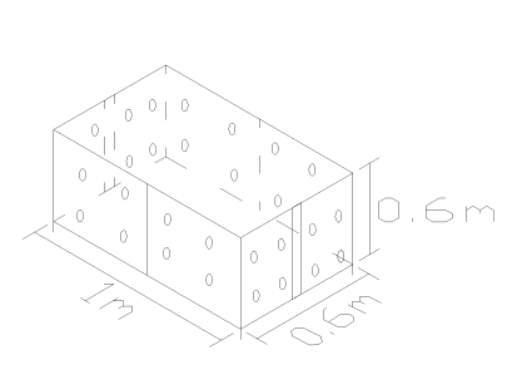

(a)

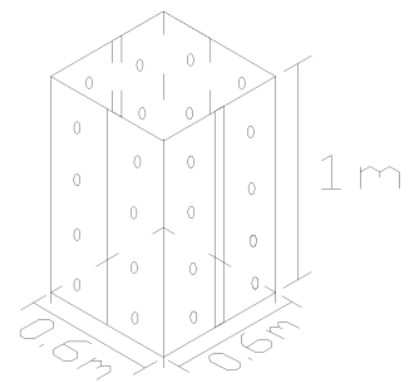

(b)

Gambar 1. (a) Rancangan Komposter T-I; (b) Rancangan Komposter T-II

Pada penelitian ini, perbedaan tinggi tumpukan kompos selama proses pengomposan merupakan variabel yang diperhatikan untuk dilihat pengaruhnya terhadap jumlah bakteri Escherichia coli dan Salmonella sp. Sehingga, komposter dibuat dengan 2 variasi dimensi bak yang berbeda. Dimana, 1 komposter dibuat dengan dimensi $1 \mathrm{~m} \times 0,6 \mathrm{~m} \times 0,6 \mathrm{~m}$ (T-I) dan komposter lainnya dibuat dengan dimensi 0,6 $\mathrm{m} \times 0,6 \mathrm{~m} \times 1 \mathrm{~m}$ (T-II) dengan masing-masing frekuensi pengadukan 4 hari sekali. Selain itu, persiapan peralatan yang diperlukan dan mendukung selama proses pengomposan juga harus diperhatikan. Adapun peralatan yang digunakan yaitu masker pelindung, sarung tangan, plastik sampah, plastic flip, mesin pencacah, termometer tanah manual dan digital, sekop dan meteran bangunan.

Proses Pengomposan

Proses pengomposan pada penelitian ini dimulai dengan mengumpulkan bahan baku kompos berupa sampah buah dan sayur dari pasar angso duo Kota Jambi dan limbah padat berupa isi rumen dan kotoran sapi dari RPH Kota Jambi. Sampah buah, sayur, isi rumen dan kotoran sapi yang telah dikumpulkan kemudian diangkut menuju TPA Talang Gulo Kota Jambi. Sampah buah dan sayur memiliki ukuran yang besar sehingga tidak dapat langsung digunakan sebagai bahan baku kompos. Murbandono (2008) menjelaskan bahwa ukuran sampah yang optimal untuk pengomposan berkisar 0,32$1,50 \mathrm{~cm}$. Oleh karena itu, sampah buah dan sayur harus dicacah terlebih dahulu. Sampah buah dan sayur yang telah dikumpulkan, dicacah dengan menggunakan mesin pencacah merek Yanmar.

Sampah buah dan sayur yang telah dicacah serta isi rumen dan kotoran sapi memiliki kadar air yang tinggi. Selama proses pengomposan, jika bahan baku kompos dipenuhi air, maka jumlah oksigen yang masuk akan berkurang dan mengganggu proses pengomposan (Widarti et al., 2015). Kadar air yang 
tinggi pada bahan baku kompos dapat dikurangi dengan melakukan penjemuran. Penjemuran dilakukan langsung dibawah matahari selama 1 hari $(24 \mathrm{jam})$ sebelum pengomposan. Bahan baku kompos yang telah dijemur selanjutnya siap untuk dikomposkan. Proses pengomposan dimulai dengan membuat campuran bahan baku kompos atau komposisi kompos. Perbandingan bahan baku yang digunakan yaitu sebanyak $38 \mathrm{~kg}$ sampah buah dan sayur, $5 \mathrm{~kg}$ isi rumen dan $5 \mathrm{~kg}$ kotoran (38:5:5) atau sebanyak $48 \mathrm{~kg}$ bahan baku kompos dalam sekali pencampuran.

Setelah bahan baku dicampur, campuran bahan baku tersebut selanjutnya dimasukkan kedalam komposter dengan tinggi tumpukan $0,6 \mathrm{~m}$ (T-I) dan $1 \mathrm{~m}$ (T-II) secara bertahap sampai bahan baku memenuhi komposter. Pada penelitian ini, dilakukan 7 kali pencampuran bahan baku untuk masingmasing komposter T-I dan T-II. Komposter T-I dan T-II memiliki volume yang sama yaitu $0,36 \mathrm{~m}^{3}$ atau setara dengan $336 \mathrm{~kg}$. Selama proses pengomposan, kompos diaduk 4 hari sekali dan pengukuran suhu kompos dilakukan setiap hari. Adapun proses pengomposan dapat dilihat pada skema proses pengomposan (Gambar 2) berikut ini.
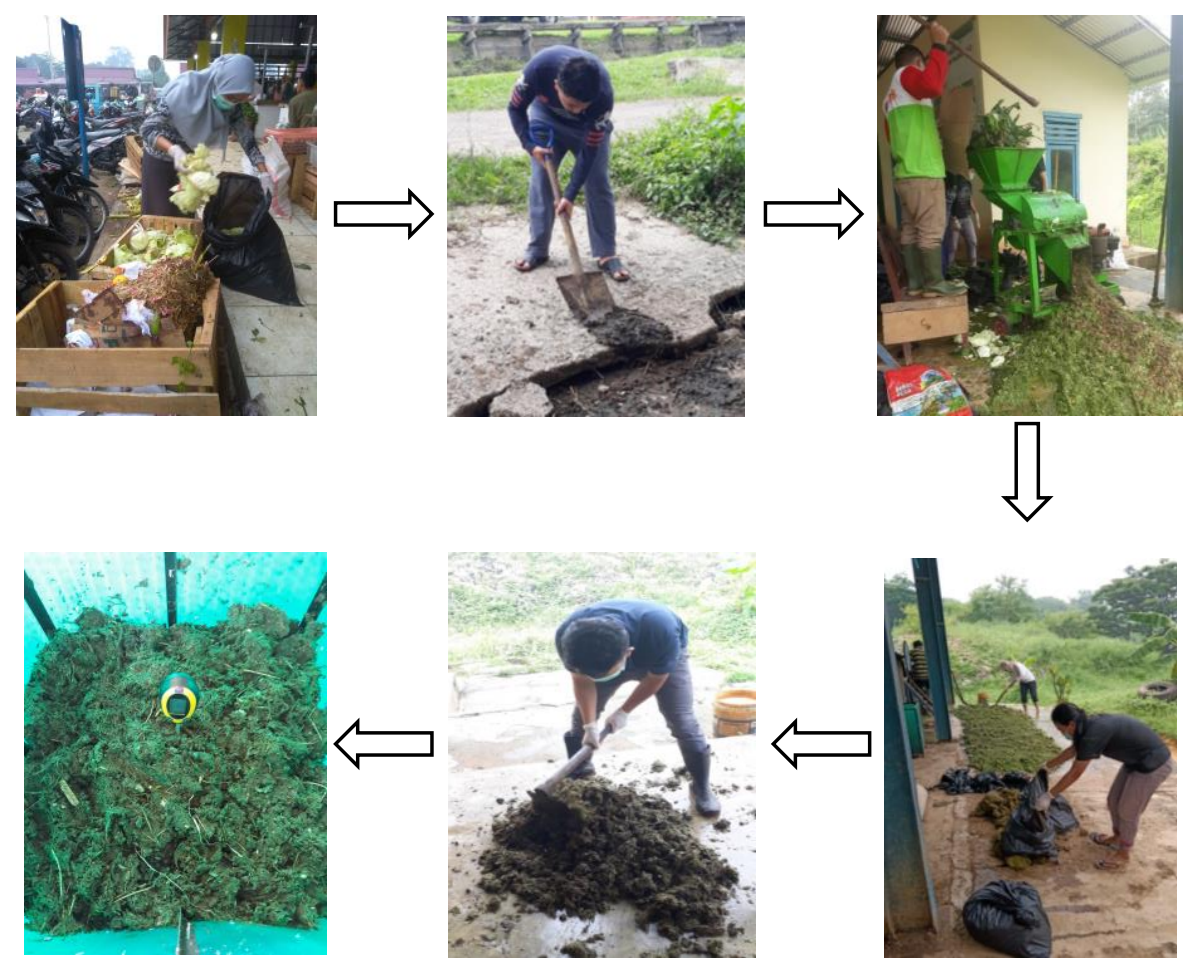

Gambar 2. Proses Pengomposan

Sumber: Dokumentasi Penelitian, 2019

c. Teknik Pengumpulan Data

Ada 2 jenis data yang digunakan dalam penelitian ini yaitu data primer dan data sekunder. Data primer didapat dengan melakukan observasi dan pengukuran terhadap kualitas kompos yang dihasilkan seperti temperatur, jumlah bakteri Escherichia coli dan Salmonella sp., volume, bau, warna, serta tekstur kompos (Tabel 1). Sedangkan, data sekunder digunakan untuk melengkapi teori dasar dan membantu dalam membuat analisis dari data yang diperoleh. Data sekunder meliputi pengumpulan data dan informasi terkait dengan materi penelitian, antara lain jumlah hewan yang dipotong setiap hari, bulan dan tahun yang diperoleh dari Rumah Potong Hewan (RPH) Kota Jambi. Serta studi literatur terkait topik penelitian dari buku dan jurnal. 
Tabel 1. Data Primer Penelitian

\begin{tabular}{cccc}
\hline Data & Jenis & Waktu Pengambilan Data & Metode Pengukuran \\
\hline Data & Primer & Setiap hari & Termometer \\
Temperatur & & digital dan analog \\
Jumlah Escherichia coli & Primer & Hari ke-0, 15,30 dan 45 & Most Probable Number (MPN) \\
Jumlah Salmonella sp. & Primer & Hari ke-0, 15, 30 dan 45 & Angka Lempeng Total (ALT) \\
Volume & Primer & Hari ke-0, 15, 30 dan 45 & Meteran bangunan \\
Warna & Primer & Hari ke-0 dan 45 & Organoleptik \\
Tekstur & Primer & Hari ke-0 dan 45 & Organoleptik \\
Bau & Primer & Hari ke-0 dan 45 & Organoleptik \\
\hline
\end{tabular}

d. Teknik Analisis Data

Dalam penelitian ini, analisis data dilakukan dengan menggunakan analisis statistik deskriptif. Menurut Suwarjana (2016) statistik deskriptif merupakan jenis statistik yang digunakan untuk menjelaskan atau mengkarakteristikan data dengan meringkasnya agar lebih dipahami tanpa kehilangan atau merubah informasi. Untuk memudahkan analisis, maka data akan dibuat dalam bentuk grafik dengan menghubungkan beberapa variabel, antara lain:

1. Data umur kompos dan suhu

2. Data umur kompos dan jumlah bakteri Escherichia coli

3. Data umur kompos dan jumlah bakteri Salmonella sp.

\section{Hasil Penelitian dan Pembahasan}

a. Analisis Perbedaan Tinggi Tumpukan Kompos pada Komposter T-I dan T-II terhadap Pencapaian Suhu Kompos

Penelitian ini menggunakan 2 variasi tinggi tumpukan yaitu tinggi tumpukan 0,6 m (T-I) dan tinggi tumpukan $1 \mathrm{~m}$ (T-II). Tinggi tumpukan kompos 0,6 $\mathrm{m}$ (T-I) memiliki arti bahwa kompos ditumpuk dengan tinggi $0,6 \mathrm{~m}$ di dalam komposter dengan volume $0,36 \mathrm{~m}^{3}$. Sedangkan, kompos dengan tinggi tumpukan $1 \mathrm{~m}$ (T-II) memiliki arti bahwa kompos ditumpuk dengan tinggi $1 \mathrm{~m}$ di dalam komposter dengan volume yang sama (Gambar 3).

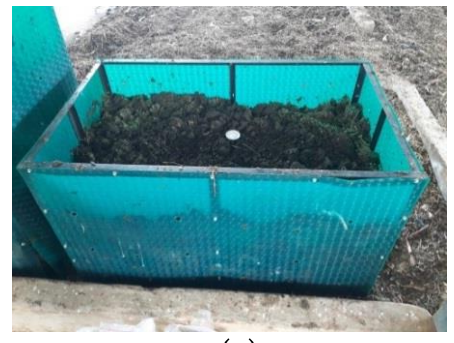

(a)

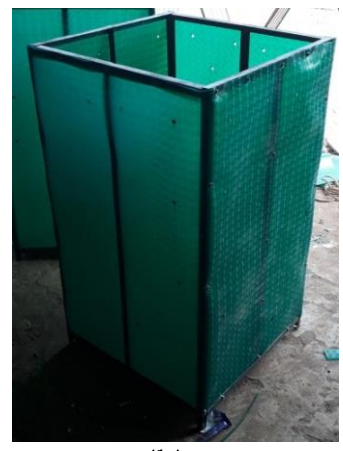

(b)

Gambar 3. (a) Komposter dengan Tinggi Tumpukan 0,6 m (T-I); (b) Komposter dengan Tinggi

Tumpukan $1 \mathrm{~m}$ (T-II)

Sumber: Dokumentasi Penelitian, 2019

Selama proses pengomposan, dilakukan 1 kali pengadukan dalam kurun waktu 4 hari $(4 \times 24$ jam). Pengadukan sebagai proses aerasi secara alami pada kompos, dilakukan secara manual menggunakan 
cangkul dan garpu rumput. Pengadukan selama 30 menit atau sampai semua kompos diaduk rata. Pada penelitian ini, pengukuran suhu kompos dilakukan setiap hari selama proses pengomposan atau selama 45 hari pengomposan. Pengukuran suhu kompos dilakukan pada bagian atas, tengah dan bawah komposter. Pengukuran suhu kompos menggunakan termometer tanah manual dan termometer tanah digital (Gambar 4).

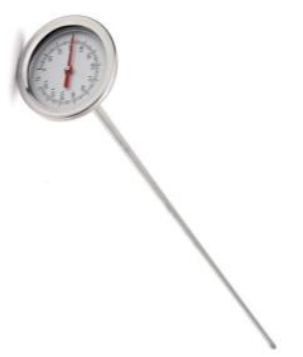

(a)

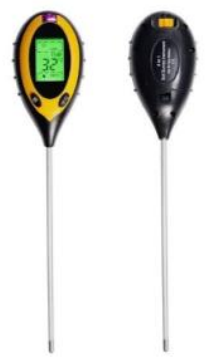

(b)

Gambar 4. (a) Termometer Tanah Manual; (b) Termometer Tanah Digital Sumber: Dokumentasi Penulis, 2019

Berikut data hasil pengukuran suhu selama proses pengomposan dalam bentuk grafik (Gambar 5).

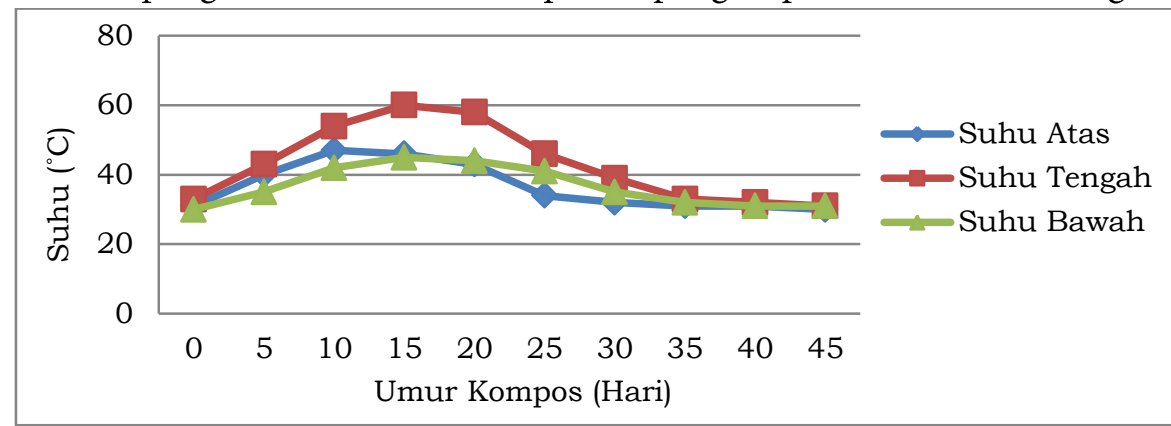

(a)

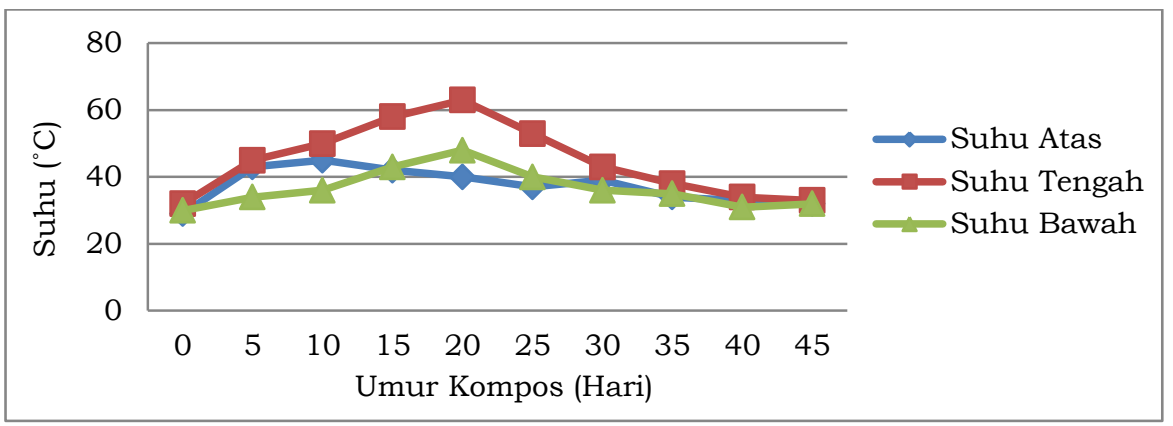

(b)

Gambar 5. (a) Grafik Suhu Kompos pada Komposter T-I; (b) Grafik Suhu Kompos pada Komposter T-II Sumber: Data Hasil Olahan, 2019

Tchobanoglous (2002) menjelaskan bahwa, terdapat 3 fase dalam pengomposan yaitu lag phase, active phase dan maturation phase. Lag phase atau initial lag period sebagai fase awal pengomposan merupakan fase adaptasi atau penyesuaian mikroba setelah proses pengomposan terbentuk. Selama Lag phase suhu kompos akan semakin meningkat berkisar $40^{\circ} \mathrm{C}$ (Insam dan Bertoldi, 2007). Suhu kompos selama lag phase pada komposter T-I tidak menunjukkan kenaikan suhu yang tinggi jika dibandingkan dengan komposter T-II. Berdasarkan hasil pengukuran suhu kompos pada komposter T-I, suhu awal yaitu $31^{\circ} \mathrm{C}$ pada bagian atas, $33^{\circ} \mathrm{C}$ pada bagian tengah dan $30^{\circ} \mathrm{C}$ pada bagian bawah komposter. 
Kenaikan suhu yang lebih tinggi selama lag phase terjadi pada komposter T-II. Dimana suhu awal pengomposan pada komposter T-II yaitu $29^{\circ} \mathrm{C}$ pada bagian atas, $32^{\circ} \mathrm{C}$ pada bagian tengah dan $30^{\circ} \mathrm{C}$ pada bagian bawah komposter. Fase selanjutnya adalah active phase atau disebut juga exponential growth phase yang berarti pada fase ini terjadi peningkatan jumlah mikroorganisme secara eksponensial. Jumlah mikroorganisme yang banyak sebanding dengan aktivitasnya yang semakin tinggi dalam menguraikan substrat yang terkandung didalam kompos. Suhu saat active phase dapat mencapai $70^{\circ} \mathrm{C}$ atau lebih (Tchobanoglous and Kreith, 2002).

Pencapaian suhu tertinggi selama active phase pada komposter T-II terjadi pada hari ke 12 sebesar $47^{\circ} \mathrm{C}$ di komposter bagian atas, hari ke 19 sebesar $64^{\circ} \mathrm{C}$ di komposter bagian tengah, dan hari ke 20 sebesar $48^{\circ} \mathrm{C}$ di komposter bagian bawah. Pencapaian suhu tertinggi lebih cepat terjadi pada komposter T-I, dimana suhu mencapai $48^{\circ} \mathrm{C}$ pada hari ke 11 di komposter bagian atas, $63^{\circ} \mathrm{C}$ pada hari ke 18 di komposter bagian tengah dan $48^{\circ} \mathrm{C}$ pada hari ke 17 di komposter bagian bawah. Selanjutnya, penurunan suhu terus terjadi baik pada komposter T-I maupun komposter T-II.

Penurunan suhu kompos terjadi setelah mencapai suhu tertinggi dari masing-masing bagian komposter. Penurunan suhu kompos mulai terjadi pada hari ke 19 pengomposan pada komposter T-I dan hari ke 20 pengomposan pada komposter T-II. Selama active phase pula, suhu kompos akan mengalami naik turun atau disebut plateau. Naik turunnya suhu kompos menunjukkan bahwa adanya aktivitas mikroorganisme. Plateau berlangsung selama beberapa hari atau beberapa minggu jika substrat yang terkandung dalam kompos masih tinggi (Tchobanoglous and Kreith, 2002).

Fase terakhir pengomposan adalah maturation phase atau curing phase. Selama maturation phase berlangsung, jumlah substrat yang terkandung didalam kompos semakin berkurang sehingga aktivitas mikroorganisme dalam mendekomposisi kompos menjadi sedikit pula. Oleh karena itu, suhu kompos akan semakin menurun selama maturation phase. Pada maturation phase pula, proses pematangan kompos mulai terjadi. Penurunan suhu tidak bisa dihindari sampai kompos mencapai suhu lingkungan. Maturation phase berlangsung pada hari ke 31 pengomposan sampai dengan hari ke 60 pengomposan.

Pada komposter T-I, suhu kompos di bagian atas komposter adalah $30^{\circ} \mathrm{C}$ dan suhu $31^{\circ} \mathrm{C}$ di bagian tengah dan bawah komposter pada hari ke-45 pengomposan. Sedangkan pada komposter T-II, suhu $32^{\circ} \mathrm{C}$ di bagian atas dan bawah komposter serta $33^{\circ} \mathrm{C}$ di bagian tengah komposter pada hari ke- 45 pengomposan. Hal ini menunjukkan bahwa suhu masing-masing kompos di komposter T-I dan T-II pada hari ke-45 pengomposan belum memenuhi baku mutu untuk suhu kompos berdasarkan SNI 19-70302004 yaitu sesuai dengan suhu air tanah atau sebesar $27^{\circ} \mathrm{C}$.

b. Analisis Perbandingan Tinggi Tumpukan Kompos terhadap Jumlah Bakteri Escherichia coli

Pengujian terhadap bakteri Escherichia coli dilakukan dengan menggunakan metode MPN (Most Probable Number). Pengujian sampel Escherichia coli dilakukan pada hari ke-0, 15, 30, dan 45. Adapun perbandingan jumlah bakteri Escherichia coli dan suhu yang dicapai selama pengomposan pada komposter T-I dapat dilihat pada grafik (Gambar 6).

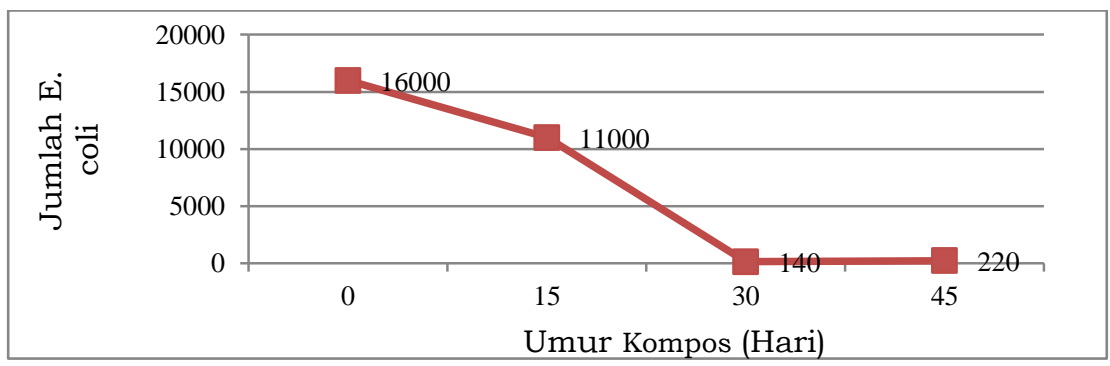

Gambar 6. Grafik Perbandingan Jumlah Bakteri Escherichia coli dan Suhu pada Komposter T-I Sumber: Data Hasil Olahan, 2019 
Jumlah bakteri Escherichia coli pada awal pengomposan sangat tinggi baik pada komposter T-I maupun komposter T-II yaitu sebesar 16.000 MPN/gr. Hal ini menunjukkan bahwa bahan baku kompos mengandung bakteri Escherichia coli yang tinggi terutama bahan baku isi rumen dan kotoran sapi yang berasal dari rumah potong hewan (RPH) Kota Jambi. Perbedaan tinggi tumpukan kompos menghasilkan pencapaian suhu yang berbeda. Begitu pula dengan pencapaian suhu yang juga mempengaruhi aktivitas mikroorganisme didalam kompos termasuk bakteri Escherichia coli.

Pengujian bakteri Escherichia coli pengomposan hari ke-15 terlihat penurunan jumlah bakteri Escherichia coli sebesar 31,25\% menjadi $11.000 \mathrm{MPN} / \mathrm{gr}$. Setelah active phase, fase pengomposan dilanjutkan dengan maturation phase. Suhu kompos pada maturation phase masih cukup tinggi meskipun semakin lama pengomposan suhu kompos akan turun secara perlahan. Terlihat pada Gambar 11, bahwa jumlah bakteri Escherichia coli menurun sangat banyak pada hari ke-30 pengomposan setelah melewati active phase menjadi $140 \mathrm{MPN} / \mathrm{gr}$ atau penurunan jumlah bakteri Escherichia coli sebesar $67,48 \%$.

Pengujian bakteri Escherichia coli dilanjutkan pada hari ke-45 pengomposan. Jumlah bakteri Escherichia coli kembali mengalami kenaikan yaitu menjadi 220 MPN/gr. Kenaikan jumlah bakteri Escherichia coli sebanding pula dengan kenaikan rasio C/N pada komposter T-I. Menurut Siagian (2020), pengujian terhadap rasio $\mathrm{C} / \mathrm{N}$ pengomposan hari ke-45 mencapai 32,12:1. Yang berarti bahwa tersedianya substrat yang cukup untuk bakteri Escherichia coli bisa tumbuh dan berkembang biak. Jumlah bakteri Escherichia coli sebanyak 220 MPN/gr belum memenuhi syarat berdasarkan Peraturan Menteri Pertanian Nomor 70 Tahun 2011 tentang Pupuk Organik, Pupuk Hayati dan Pembenah Tanah. Data hasil pengujian suhu dan jumlah bakteri Escherichia coli pada komposter T-II dapat dilihat pada grafik (Gambar 7).

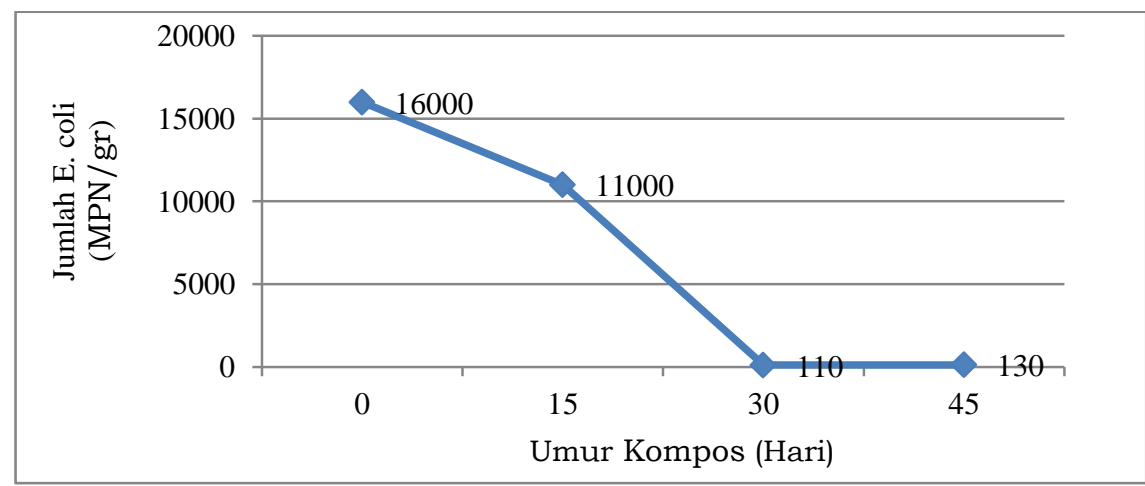

Gambar 7. Grafik Perbandingan Jumlah Bakteri Escherichia coli dan Suhu Pada Komposter T-II Sumber: Data Hasil Olahan, 2019

Berdasarkan Gambar 7, terlihat bahwa jumlah bakteri Escherichia coli pada komposter T-II sebanyak 16.000 MPN/gr pada awal pengomposan. Selanjutnya penurunan jumlah bakteri Escherichia coli sebesar 31,25\% terjadi pada pengujian jumlah bakteri Escherichia coli hari ke-15 pengomposan. Sama halnya dengan komposter T-I, suhu kompos $\geq 55^{\circ} \mathrm{C}$ terjadi pada active phase. Setelah melewati active phase, jumlah bakteri Escherichia coli kembali mengalami penurunan menjadi $110 \mathrm{MPN} / \mathrm{gr}$ pada hari ke30 pengomposan atau penurunan jumlah bakteri Escherichia coli sebesar 66,21\%. Pengujian pada hari ke45 pengomposan, jumlah bakteri Escherichia coli kembali mengalami kenaikan menjadi $130 \mathrm{MPN} / \mathrm{gr}$.

Mengacu pada penelitian Hutagalung (2012), bahwa peristiwa yang sama dimana jumlah bakteri kembali meningkat pada maturation phase atau disebut dengan istilah regrowth bacteria. Pengukuran suhu kompos dilakukan pada bagian atas, tengah dan bawah komposter. Meskipun suhu kompos mencapai suhu termofilik pada active phase, namun hal ini tidak menjamin bahwa suhu tersebut merata pada seluruh bagian komposter. Sehingga, suhu yang tidak rata inilah yang dapat menyebabkan bakteri Escherichia coli dapat lolos dan kembali berkembang biak. 
Kenaikan jumlah bakteri Escherichia coli pada komposter T-II lebih sedikit jika dibandingkan dengan komposter T-I. Meskipun demikian, jumlah bakteri Escherichia coli pada komposter T-II hari ke45 pengomposan masih belum memenuhi persyaratan jumlah bakteri Escherichia coli yang disyaratkan pada Peraturan Menteri Pertanian No. 70 tahun 2011 tentang Pupuk Organik, Pupuk Hayati dan Pembenah Tanah yaitu sebesar 100 MPN/gr.

c. Perbandingan Tinggi Tumpukan Kompos Terhadap Jumlah Bakteri Salmonella sp.

Pengujian terhadap bakteri Salmonella sp. dilakukan dengan menggunakan metode angka lempeng total (ALT) dengan teknik cawan tuang atau pour plate. Berdasarkan hasil uji, limbah padat RPH Kota Jambi dinyatakan negatif. Pengujian terhadap bakteri Salmonella sp. selanjutnya dilakukan pada kompos hari ke-0 pengomposan. Hasil pengujian menunjukkan hasil yang sama dengan pengujian bakteri Salmonella sp. pada limbah padat RPH Kota Jambi, yaitu negatif. Hal ini menunjukkan bahwa bahan baku kompos, baik isi rumen dan kotoran sapi maupun sampah buah dan sayur tidak terkontaminasi oleh bakteri Salmonella sp. Sehingga, dapat disimpulkan bahwa kompos pada komposter T-I maupun komposter T-II bebas dari kontaminasi bakteri Salmonella sp.

\section{d. Analisis Kematangan Kompos}

Kematangan kompos merupakan keadaan dimana kompos telah siap digunakan sebagai penyubur tanah (Hutagalung, 2012). Pada penelitian ini ada beberapa parameter kematangan kompos yang akan diuji yaitu volume, bau, warna dan tekstur kompos berdasarkan SNI 19-7030-2004 tentang Spesifikasi Kompos dari Sampah Organik Domestik. Pengukuran volume kompos dilakukan dengan menggunakan meteran dari bagian luar komposter (Gambar 8).

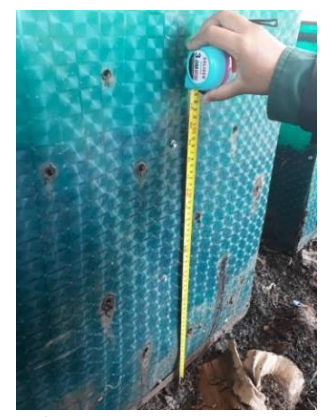

Gambar 8. Pengukuran Tinggi Tumpukan Kompos Sumber: Dokumentasi Penelitian, 2019

Pengukuran volume kompos dilakukan pada hari ke 0 sebagai awal dilakukannya pengomposan, kemudian pada hari ke 15, 30 dan 45. Volume awal pengomposan masing-masing komposter adalah 0,36 $\mathrm{m}^{3}$. Hasil pengukuran selanjutnya dihitung secara matematis. Menurut Canadian Council of Ministry of Environment dalam Guidelines for Compost Quality (1996) kompos dapat dikatakan telah matang apabila reduksi material organiknya mencapai $60 \%$. Adapun reduksi volume selama pengomposan pada komposter T-I dan T-II dapat dilihat pada grafik (Gambar 9).

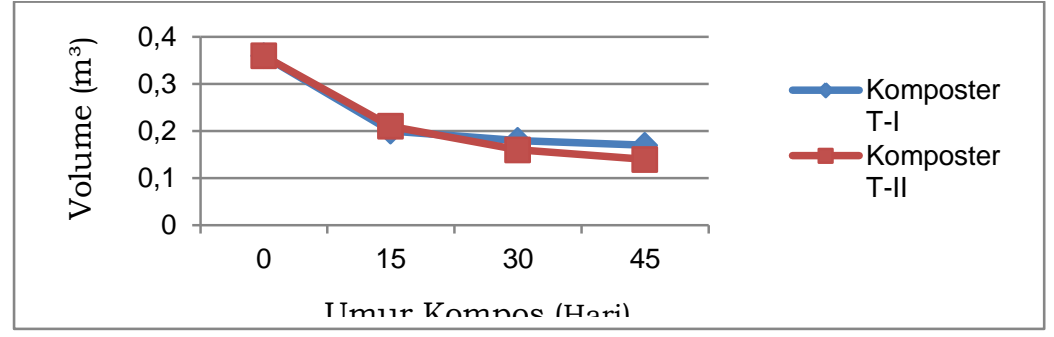

Gambar 9. Reduksi Volume Kompos

Sumber: Data Hasil Olahan, 2019 
Dari Gambar 9 dapat dilihat bahwa pada hari ke-15 pengomposan, reduksi volume kompos pada komposter T-I sebesar 45\% lebih besar jika dibandingkan dengan reduksi volume kompos pada komposter T-II yang hanya 40\%. Namun hal yang sebaliknya terjadi pada hari ke-45 pengomposan. Dimana, reduksi volume yang lebih tinggi terjadi pada komposter T-II sebesar $61 \%$ dan komposter T-I sebesar 53,3\%. Jadi dapat disimpulkan bahwa, kompos pada komposter T-I belum matang karena reduksinya hanya $53,3 \%$ sedangkan kompos pada komposter T-II telah matang dengan total reduksinya sebesar $61 \%$.

Analisis kematangan kompos berdasarkan bau dilakukan dengan menggunakan metode organoleptik. Metode ini didasarkan pada proses pengindraan seperti penglihatan, penciuman, dan perasa. Kompos pada hari ke-0 berbau seperti sampah busuk dan bau menyengat dari isi rumen dan kotoran sapi. Namun, pada hari selanjutnya bau pada kompos semakin berkurang dan bau busuk pada awal pengomposan akan digantikan oleh bau tanah yang mengindikasi kompos telah matang (Anif et al., 2007) sesuai dengan SNI 19-7030-2004 tentang Spesifikasi Kompos dari Sampah Organik Domestik.

Analisis warna dan tekstur kompos dilakukan menggunakan metode organoleptik atau penilaian sensorik menggunakan indra seperti mata dan kulit. Pada awal pengomposan, bahan baku kompos berwarna hijau kecoklatan (Gambar 10). Warna tersebut berasal dari warna sampah buah dan sayur yang dominan berwarna hijau serta limbah padat rumah potong hewan yang berwarna kecoklatan. Kompos yang berwarna hijau kecoklatan selama pengomposan berubah warna menjadi kehitaman pada hari ke- 45 .

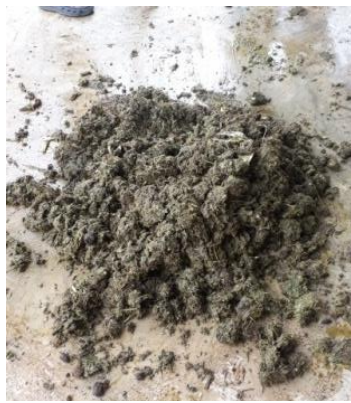

(a)

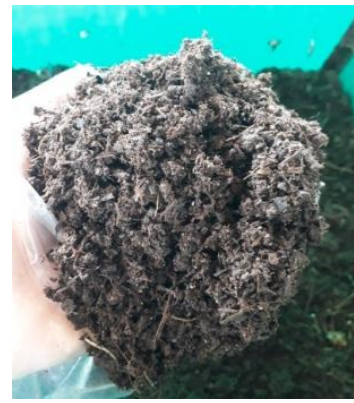

(b)

Gambar 10. (a) Kompos Hari Ke-0; (b) Kompos Hari Ke-45

Sumber: Dokumentasi Penelitian, 2019

Tekstur kompos saat awal pengomposan adalah kasar dan masih terdapat banyak gumpalan dari bahan baku kompos (Gambar 10), dan apabila dipegang terasa basah karena kadar air yang masih tinggi. Sampah buah dan sayur yang telah dicacah tidak dapat dibedakan jika sudah tercampur dengan limbah rumah potong hewan. Semakin lama waktu pengomposan, tekstur kompos yang awalnya menggumpal perlahan terurai dan halus menyerupai tektur tanah seperti kriteria kematangan kompos dalam SNI 197030-2004.

\section{Kesimpulan}

Berdasarkan pengolahan data dan analisa hasil yang telah dilakukan, maka dapat ditarik kesimpulan dari penelitian ini adalah sebagai berikut:

1. Perbedaan tinggi tumpukan kompos mempengaruhi pencapaian suhu kompos. Komposter dengan tinggi tumpukan kompos $0,6 \mathrm{~m}$ (T-I) mencapai suhu tertinggi $63^{\circ} \mathrm{C}$. Sedangkan, komposter dengan tinggi tumpukan $1 \mathrm{~m}$ (T-II) mencapai suhu tertinggi $64^{\circ} \mathrm{C}$.

2. Perbedaan tinggi tumpukan kompos mempengaruhi jumlah bakteri Escherichia coli pada kompos. Pada komposter T-I dan T-II penurunan jumlah bakteri Escherichia coli dari 16.000 MPN/gr menjadi $130 \mathrm{MPN} / g r$ dan $110 \mathrm{MPN} / g r$ pada hari ke-45 pengomposan. Namun, jumlah ini belum sesuai dengan yang disyaratkan pada Peraturan Menteri Pertanian Nomor 70 Tahun 2011 tentang Pupuk Organik, Pupuk Hayati dan Pembenah Tanah. 
3. Pengomposan dengan memanfaatkan sampah organik dari Pasar Angso Duo Kota Jambi dan limbah Rumah Potong Hewan (RPH) Kota Jambi sebagai bahan baku kompos bebas dari kontaminasi bakteri Salmonella sp.

4. Perbedaan tinggi tumpukan kompos tidak mempengaruhi parameter kematangan kompos. Parameter kematangan kompos yaitu bau, warna dan tekstur kompos pada komposter T-I dan T-II sudah sesuai dengan parameter kematangan kompos berdasarkan SNI 19-7030-2004 tentang Spesifikasi Kompos dari Sampah Organik Domestik.

\section{Saran}

Berdasarkan penelitian yang telah dilakukan maka saran yang dapat diberikan adalah sebagai berikut:

1. Untuk semakin mengurangi jumlah bakteri Escherichia coli, sebaiknya pengujian terus dilakukan hingga maturation phase pada kompos berakhir yaitu pada hari ke-60 pengomposan.

2. Pengomposan dengan metode open windrow sebaiknya dilakukan pada tempat yang benar-benar terhindar dari tempias air hujan agar tidak mempengaruhi suhu dan kelembaban kompos selama pengomposan.

3. Untuk mendapatkan suhu kompos yang optimal pada komposter, sebaiknya sebelum dikomposkan bahan baku kompos dijemur lebih lama untuk mengurangi kadar air didalam kompos dan menghindari kompos terendam air pada bagian bawah komposter.

4. Perlu adanya penelitian lanjutan terhadap variasi tinggi tumpukan kompos yang lebih banyak selain tinggi tumpukan 60 dan $100 \mathrm{~cm}$.

\section{Daftar Pustaka}

[1] Amanah, F. (2012). Pengaruh Pengadukan dan Bahan Baku terhadap Kualitas Kompos Campuran Lumpur Tinja. Skripsi. Universitas Indonesia, Depok.

[2] Anif, S. T. Rahayu. dan M. Faatih. (2007). Pemanfaatan Limbah Tomat sebagai Pengganti Em-4 pada Proses Pengomposan Sampah Organik. Jurnal Penelitian Sains dan Teknologi. 8(2): 119-143.

[3] Badan Standarisasi Nasional. 2004. SNI 19-7030-2004 tentang Spesifikasi Kompos dari Sampah Organik Domestik. Badan Standarisasi Nasional, Jakarta.

[4] Canadian Council of Ministry of Environment. (1996). Guidelines for Compost Quality. Manitoba Statutory Publications, Winnipeg.

[5] Erwiyono, R. (1994). Pengaruh Pemberian Pupuk Kandang dan Aerasi Terhadap Mutu Kompos Limbah Organik Pabrik Kertas. Jurnal Mikrobiologi Indonesia. 11(2): 2-3.

[6] Hutagalung, W. L. C. 2012. Pengaruh Pengadukan terhadap Jumlah Fecal coliform dan Salmonella sp. Kompos Lumpur Tinja pada IPLT Kalimulya Depok. Skripsi. Universitas Indonesia, Depok.

[7] Insam, H. dan M. D. Bertoldi. (2007). Mycrobiology of the Composting Process. Waste Management Series. 8: 25-48.

[8] Marolop, G. (2015). Perkiraan Timbulan Sampah Kota Jambi Tahun 2015. Jurnal Ilmiah Universitas Batanghari Jambi. 15(4): 41-44.

[9] Murbandono, L. (2008). Membuat Kompos. Penebar Swadaya, Jakarta.

[10] Peraturan Menteri Pertanian Nomor 70/Permentan/SR.140/2011 tentang Pupuk Organik, Pupuk Hayati dan Pembenah Tanah.

[11] Setiawan, B. S. (2010). Membuat Pupuk Kandang Secara Cepat. Penebar Swadaya, Bogor.

[12] Siagian, S. N. (2020). Pengaruh Perbedaan Tinggi Tumpukan Komposter Aerobik Open Windrow terhadap Kualitas dan Kuantitas Kompos Sampah Organik Pasar dengan Limbah Padat Rumah Potong Hewan. Skripsi. Universitas Jambi, Jambi. 
[13] Tarigan, S. (2012). Pembuatan Pupuk Organik Cair dengan Memanfaatkan Limbah Padat Sayuran Kubis (Brassica aleracege 1.). Universitas Sumatera Utara, Medan.

[14] Tchobanoglous, G and F. Kreith. (2002). Integrated Solid Waste Management Engineering Principles and Management Issues. Second Edition. Mc Graw Hill Inc,New York.

[15] Widarti, B. N., W. K. Wardhini. dan E. Sarwono. (2015). Pengaruh Rasio C/N Bahan Baku pada Pembuatan Kompos dari Kubis dan Kulit Pisang. Jurnal Integrasi Progres. 5(2): 75-80. 